\title{
Machines and Horticultural Implements for the Cultivation of Small-Scale Herbs and Spices
}

\author{
Witold Niemiec ${ }^{1}$, Tomasz Trzepieciński* \\ 1 Department of Water Purification and Protection, Rzeszow University of Technology, Al. Powstańców \\ Warszawy 6, 35-959 Rzeszów, Poland \\ 2 Department of Materials Forming and Processing, Rzeszow University of Technology, Al. Powstańców \\ Warszawy 8, 35-959 Rzeszów, Poland \\ * Corresponding author's e-mail: tomtrz@prz.edu.pl
}

\begin{abstract}
Herbal plants and spices, due to their aromatic and medicinal properties, are widely used in pharmacy, cooking, cosmetology and agriculture. The increase in the number of willow plantations for energy crops has enhanced the interest of the salicylic glycosides contained in the willow bark which shows multidirectional pharmacological activity. The small-scale production of herbs and spices requires the application of agricultural machines and horticultural implements adjusted to the area cultivated. In this paper, the comprehensive characteristics of the medicinal properties of willow are presented. Newly developed machines used for the mechanisation of the establishment and cultivation of herbs and spices are also described. The machines presented are a part of the technology developed at the Rzeszow University of Technology which can also be used for the mechanisation of biomass production. In order to improve the physicochemical properties of the soil and increase the amount and quality of yield, natural organic fertilisers can be used. Therefore, the paper presents the correct method of storing manure and a device for the application of solid and liquid fertilizers to the soil as well as a device for monitoring the state of the soil-water environment.
\end{abstract}

Keywords: cultivation, harvesting, herbal plants, herbs, spices, willow

\section{INTRODUCTION}

In recent years, the cultivation of herbs covers an area of about 14 thousand hectares in Poland. Athough the production of herbal food and cosmetics has an increasing economic impact, in the coming years the production of herbal plants will have the greatest impact on the Polish market for herb cultivation [Olewnicki et al. 2015]. Poland is one of the leading European countries as far as the cultivation of herbs and spices is concerned. Field cultivation of herbs on farms can be an important source of income, although those cultivating them must remember to adjust the farm production to the changing demand, consumer needs and prices. The issues of how to set up a plantation of herbal plants, how to grow them and how to obtain a high-quality raw material and a satisfactory income level are all the relevant challenges [Newerli-Guz 2016].

The cultivation of herbal plants should begin with assessing the possibility of selling the raw material. Then, trial crops should be established to check how the species behaves under specific field conditions. In addition, it is important to check the labour required for cultivation and appropriate handling of the crop after harvest [Leonti and Verpoorte 2017, Newerli-Guz 2016]. The discussion of the possible advantages of using herbal medicines instead of purified compounds as well as the truth and myths about herbal medicines have been provided by Carmonia and Pereira [2013]. The impact of the environmental factors on the size and quality of crops should also be taken into account. Thus, it becomes important to consider the methods of intensifying cultiva- 
tion in relation to the rational fertilisation adapted to the varieties of plants and how to integrate the protection of the plantation against weeds and pests [Lubbe and Verpoorte 2011, Newerli-Guz 2016]. Another important issue is the process of preserving the raw material obtained using dryers. The raw material obtained should be packed and delivered to the herbal plants purchasing centres or directly to the processing plant. Therefore, it is important to analyse the opportunities for selling the raw material produced in order to avoid the problems related to its sale and distribution.

In the case of herbal plants, the quality of the raw material is more important than the crop yield. The content of active substances determined for a specific plant determines its health properties, use in the culinary arts and cosmetology [Newerli-Guz 2016]. The products from the Polish agritourism farms can compete on the European market due to the low soil pollution in our country and low consumption of artificial fertilisers and pesticides.

Currently, more people tend to improve the quality of their lives by promoting a healthy lifestyle and rational nutrition. The valuable vitamins and minerals contained in vegetables, fruits, spices and herbs positively affect the functioning of the human organism. Herbs are also used as feed additives acting as growth promoters that favourably affect the ecosystem of the alimentary canal by inhibiting the growth of pathogenic microorganisms [Mizak et al. 2012]. The products from ecological farms are devoid of artificial fertilisers and chemicals; thus, they are considered to be healthier and provide many nutrients. The development of ecological farming in Poland is important in the structural and functional transformation of rural areas. It affects the policy of sustainable development, the improvement of the financial situation of farmers and the promotion of agritourism.

An area of land, a crop of herbs, and the use of specialised equipment in the mechanisation of the establishment, cultivation and harvesting of the crop have a significant impact on the economic efficiency of agricultural production. This paper, presents the machines and horticultural implements for the establishment, cultivation and harvesting of herbal plants for small and mediumsized farms. When considering the establishment of plantations, special attention was given to the fertilisation of the land using organic fertilisers.

\section{HARVESTING OF WILLOW BARK FOR HERBAL REMEDIES}

The natural ingredients found in the wood and bark of willow bark, are very valuable, especially the active substances in the form of salicylic glycosides, flavonoids and phenolic compounds used for pharmaceutical and cosmetic purposes. There are about 350 basic species and varieties of Salix willow in the world. Among the many species of willow, the two species are of the greatest importance for modern phytotherapy: the purple willow (Salix purpurea L.) and the white willow (Salix alba L.). The willow bark, as herbal material, is considered to be antipyretic, anti-inflammatory and analgesic. Such properties are conditioned by salicylic glycosides, which are one of the most important groups of active compounds contained in the willow bark. These glycosides easily break down in the alimentary tract, releasing salicylic alcohol, which is oxidized in the liver to salicylic acid and thus does not damage the stomach mucosa. Despite using them in viral diseases, the active compounds in the bark inhibit platelet aggregation [Waliszewska and Dukiewicz 2014].

The salicin contained in the willow bark has become the precursor of one of the best-known medicines - aspirin (acetylsalicylic acid) [Mahdi 2014, Mahdi et al. 2006]. The extract from the white willow bark (Salix alba L.) acts similarly to aspirin, but as a natural product it is slightly weaker and therefore is administered in higher doses. The most important active compounds of the Salix purpurea bark are: salicortin, tremulacin, grandydentatin, flavon glycosides, ellagic acid, populin, isosalipurposide, phenolic glycosides, tannins, salireposide, phenolics and fragilin [Schmid et al. 2001]. The chalcones, being the fraction of flavonoid compounds, exhibit multidirectional pharmacological activities, including: anti-inflammatory, antihistamine and antiulcer effect. The content of chalcones compounds in plants depends on the season and age of the plant [Forster et al. 2008], and their highest amount was found in autumn [Szczukowski et al. 2002]. In the next part of the article, the selected machines and the devices used for establishing and cultivation of the energy willow will be presented. However, the technical solutions described may be useful in the cultivation of other herbal plants and spices. 


\section{MECHANIZATION OF CULTIVATION OF HERBS AND SPICES}

\section{Fertilization}

The soil is the basic source of nutrients in plant growing. In order to improve the physicochemical properties of soil and increase the amount and quality of yield, fertilizers are used. Fertilizers are the products intended for providing nutrients to plants or increasing soil fertility. In organic growing and the cultivation of herbs and spices organic (natural) fertilizers such as manure, liquid manure, straw and compost are a source of nutrients and substances used for soil fertilization. The sewage sludge can be also used as a fertilizer [Niemiec and Wójcik 2015]. One of the factors affecting the quality of herbs is the contamination of heavy metals, which can accumulate during the cultivation, storage and processing of herbs and may have adverse effects on the consumer health [Tripathy et al. 2015]. Therefore, the sewage sludge should not be used in the cultivation of the herbal plants and spices.

Natural fertilizers are a source of nitrogen; hence, their improper storage can lead to the pollution of water reservoirs and groundwater with nitrates. For this reason, special attention is paid to the storage of natural fertilizers. The devices and tanks adapted to technological systems of animal farming should be provided for removal and storage of animal waste. Incorrect storage of animal manure can lead to the contamination of ground and surface water, and contamination of the air as a result of the emission of ammonia, methane, hydrogen sulfide, carbon dioxide or other anaerobic fermentation products.

Farmers are legally obliged to collect manure in maintenance rooms or in appropriate dunghills with side walls and a drainage system. Slurry and liquid manure must be stored only in tightly covered tanks. An example of a properly made manure tank is shown in Fig. 1. Manure loading is one of the most labor-consuming activities associated with the wastewater disposal. The subject matter of the utility model PL W-52082 is a manure loader having a rotating columnar stand with an extension arm (Fig. 1). The loader enables easy one-man operation and is effective when plunging the gripper into a prism. Furthermore, it provides operation in a significant area of the dunghill.

The agricultural use of liquid animal manure for fertilizing purposes is the most common form of its management. Depending on the size of doses and the frequency of application, slurry and liquid manure differently affect (i) the size and quality of crops and (ii) the changes in the soil environment. Liquid manure spread onto fields should be immediately mixed with the soil. The application of fertilizers, including liquid manure, is regulated by the Act of 10 July 2007 on Fertilizers and Fertilization (Journal of Laws of 2007, no. 147, item 1033) and the Regulation by the Polish Minister of Agriculture and Rural Development of 18 June 2008 on the implementation of certain provisions of the Act on Fertilizers and Fertilization (Journal of Laws of 2008, No. 119, item 765).

The richness of easily absorbed nutrients contained in the liquid manure and their high bioavailability make it an excellent natural fertilizer. The

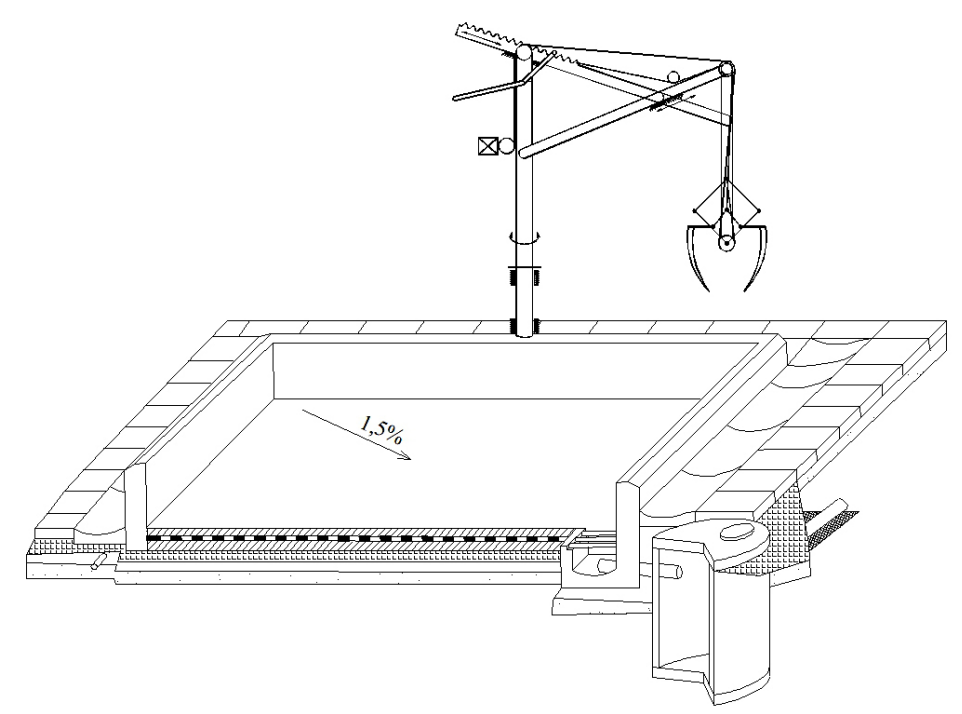

Fig. 1. Dunghill and columnar loader of manure (prepared on the basis of Habel et al. [1990]) 
bioavailability of ingredients contained in the liquid manure for plants is higher than for ordinary manure. The high content of nitrogen dissolved in water (about 50\%) makes slurry a quick-acting fertilizer [Dimitriou and Mola-Yudego 2017]. The application of liquid manure to the soil, however, is associated with the ecological and hygienic-sanitary problems. The injection or at least soil management after liquid manure applications in arable soils is a good agricultural practice because it efficiently reduces the $\mathrm{NH}_{3}$ losses.

Legally required sanitary conditions related to the application of solid and liquid fertilizers are associated with an immediate covering of the fertilizer with soil. This increases the effectiveness of fertilising. The application of organic liquid fertilisers into the soil is the main advantage of single axle trailer with the tank (Fig. 2). The device for fertilization with solid and liquid fertilizers according to the patent PL P-176563 consists of a tank (1) mounted on the supporting frame of a single axle trailer (2) using quick release couplings ( 3 ).

The tank has a rotating mixer (4) driven by the power take-off (PTO) shaft (5) of the tractor. In the rear of the tank (1) there is a liquid manure spreader (6) and a sprinkler (7). The tank can be mounted on the typical manure spreader. The liquid discharged with the use of conventional slurry tanks is poured out over a relatively short distance, which requires a large number of trips to fertilize the whole area of land. In the proposed agricultural solution, there is an impeller pump (8) in the rear of the trailer, which transports the liquid to the sprinkler (7). The rotatable sprinkler allows to control the spraying direction. The advantage of the spreader is the possibility of fertilizing smaller fields from roadways. The description of the patents and utility models used in this paper are shown at the end of the chapter 3 , in Table 1.

The device for subsurface application of liquid fertilizer (Fig. 3) meets the requirement of covering the fertilizer with soil. The basic elements of the machine are a frame bearer (1), a wheel (2), a coulter (3), damper springs $(4,6)$, a pressure roll (5) and pipe (7) supplying liquid. The details of the structure of the device are given in the description of utility model PL W-39050.

In order to control the state of the soil-water environment or the degree of bioavailability of nutrients, a lysimeter construction (Fig. 4) was developed to allow the continuous collection of groundwater samples for specialist tests. The lysimeter is used to measure the amount of actual evapotranspiration which is released by plants. The device consists of a container closed by a perforated lid with a cone-shaped bottom ending with a nozzle. The upper lid and outlet port end with flexible hoses that connect the space inside the device with its surroundings. The water from the container is collected using hoses or a portable vacuum pump.

The advantage of the device is a reinforced structure that allows the use of heavy agricultural equipment in the land without the need to bypass the place of installation of the device. More detailed data are given in the description of utility model PL W-64580.

\section{Establishing and cultivation of plants}

The growing demand for biomass, especially various forms of wood, increases the activity in the search for new machines enabling thewillow cultivation on small areas with a low amount of work. In the machinery market, there is a choice in terms of technical facilities intended for the operation in large plantations. These machines are expensive and unsuitable for farming in small crop areas [Trzepieciński et al. 2013]. Hand planting is cumbersome and is characterized by low-performance. However, specialized machines with high efficiency cannot be used on small plantations [Bergante et al. 2016].

The growing interest in wood biomass production in small mountainous areas of southern Poland leads to developing the original machines and devices for planting the energetic willow cuttings at the Rzeszow University of Technology. The planters, which are mounted on a typical agricultural tractor with the three-point suspension system, are characterized by a simple construction and high reliability.

The frame bearer of the double-row planter (Fig. 5) for the energetic willow is attached to the agricultural tractor. Each of the two working sections of the planter consists of a set of drive wheels (8). The working sections are made in a form of the drums (4) which consist of the five pipes (13), when the pipes are uniformly distributed around the drum. Cuttings (14) are placed manually by the worker in the pipes (10). During the movement of the planter, the cuttings are consecutively placed in the groove (15), and are pre-kneaded in a vertical position. Finally, the cuttings are planted into the soil by pressure wheels (5). 


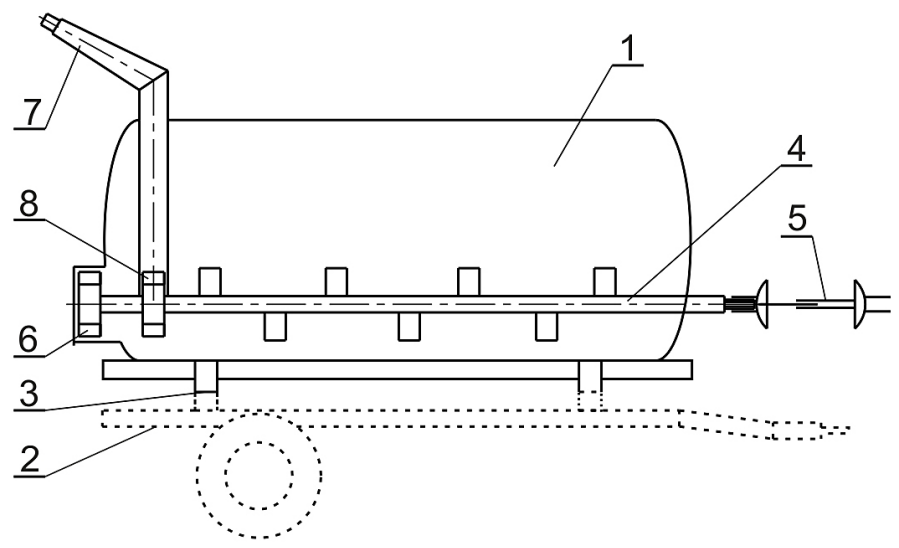

Fig. 2. The tank for fertilization of solid and liquid fertilizers: $1-\operatorname{tank}, 2$ - single axle trailer, 3 - quick release coupling, 4 - mixer, 5 - power take-off shaft, 6 - liquid manure spreader, 7 - sprinkler, 8 -impeller pump

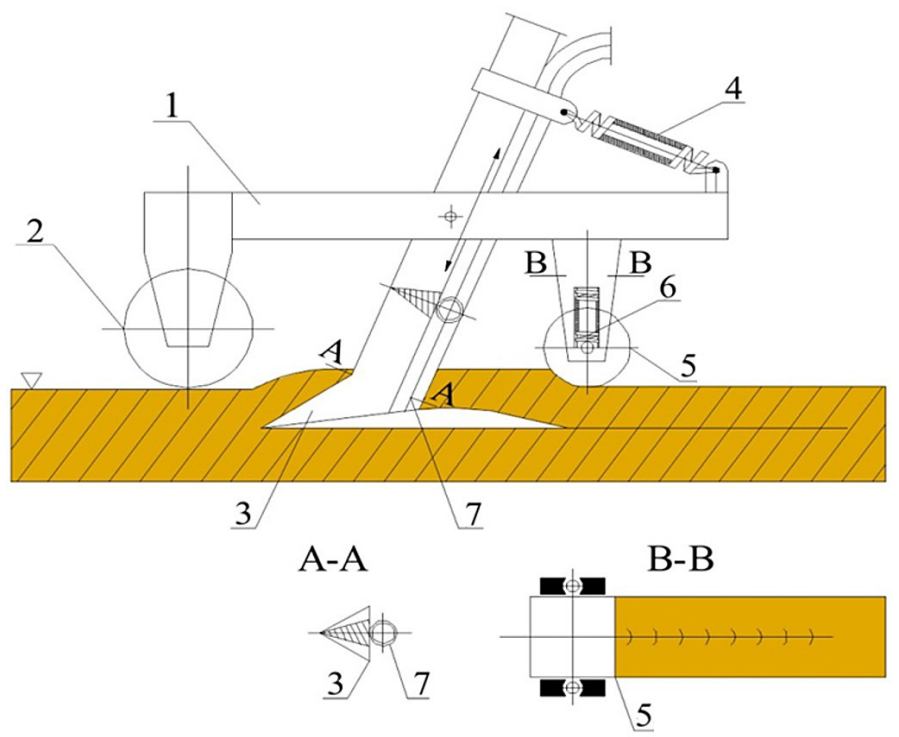

Fig. 3. The device for injecting liquid into the ground: 1 - frame bearer, 2 - roller, 3 - coulter, 4, 6 - damper springs, 5 - pressure roll, 7 - supply pipe

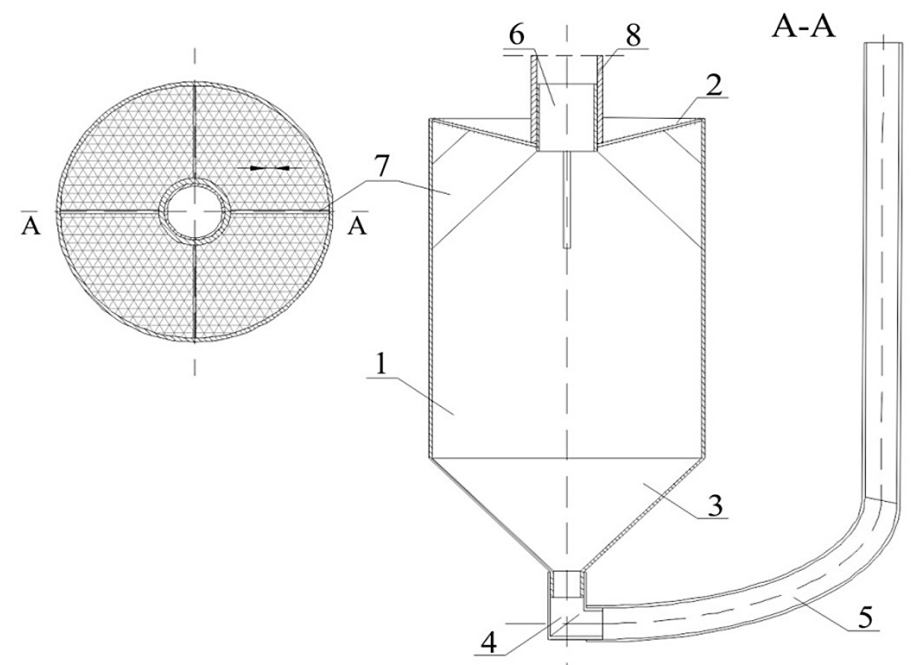

Fig. 4. Scheme of the device for collection and measurement of infiltrating water under field conditions: 1 - tank, 2 - perforated lid, 3 - conical bottom, 4 - outlet port, 5 - flexible pipe, 6 - connector pipe, 7 - brackets, 8 - nozzle cover 


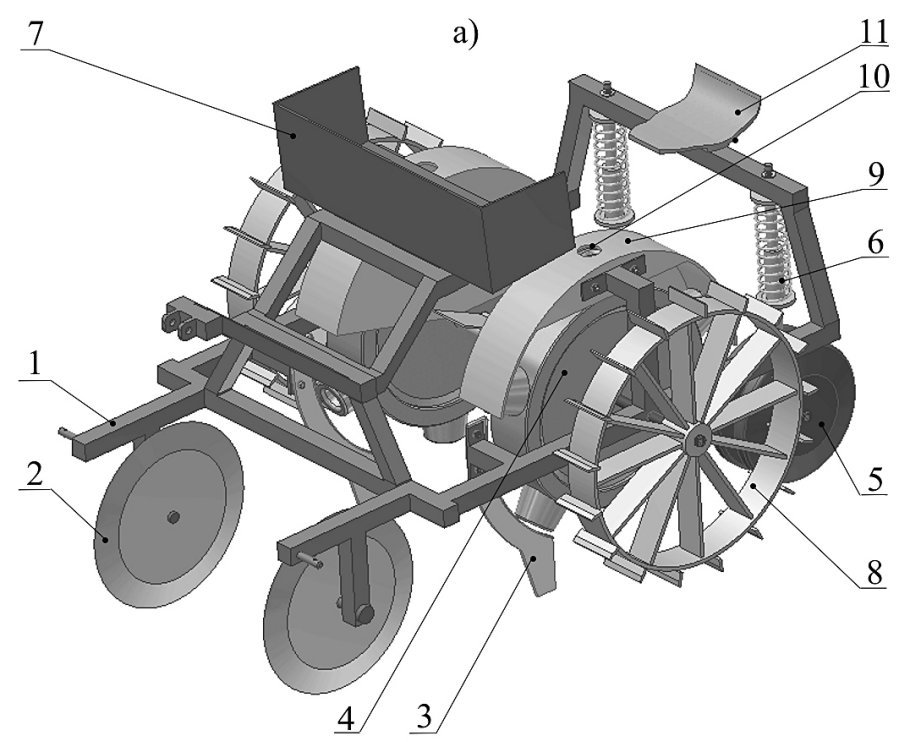

b)

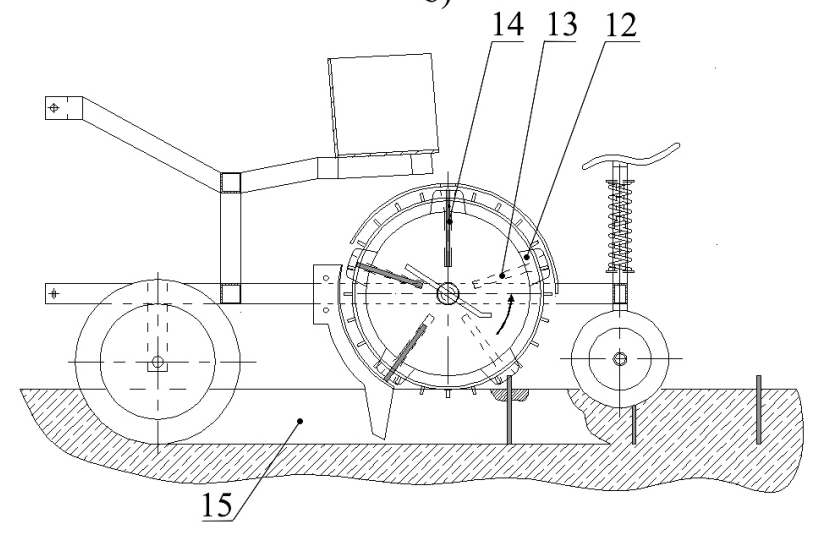

Fig. 5. Planter of plants with lignified shoots; general view (a) and cross-section (b): 1 - supporting frame, 2 - disc coulter, 3 - calibration strip, 4 - drum, 5 - pressure wheels, 6 - spring, 7 - reservoir for cuttings, 8 - drive wheel, 9 - cover, 10 - hole, 11 - seat, 12 - compaction section, 13 - pipe, 14 - cutting, 15 - groove

The presented planter requires a groove for introducing the cuttings, and finally cuttings are planted into the soil by the separate pressure wheels. This disadvantage is overcome by the track planter (Fig. 6) which gradually presses the cuttings into the soil. The planter is mounted on the tractor with the three-point suspension system (1) and is equipped with two working sections with spacing adapted to the typical spacing of willow planting (approximately $0.75 \mathrm{~m}$ ). The elimination of the furrow-forming wheels (coulters) and the calibration strips reduced the working resistances during the planting operations. The details of the planter can be found in the description of patent PL P-400110.

\section{Harvesting}

In Poland, the plantations of willow have a small area and sometimes are far apart from each other. Therefore, the use of specialized machines, even in the form of a mechanization service, is an economic barrier for the owner of the plantation [Santangelo et al. 2015, Spinelli et al. 2012]. Mechanization plays a key role in the economic implementation of shrubs short rotation. An efficient harvesting operation and proper selection of the machines are the basic assumptions for the implementation of effective crop cultivation [Vanbeveren et al. 2015]. In order to meet the needs of biomass producers, in particular those operating on small and medium-sized farms, a mower (Fig. 7) has been developed under the patent PL P-213402. The machine meets the following criteria:

- shoots should be cut without damaging the stumps, which is important from the point of view of vegetation regeneration,

- shoots should be cut as close to the soil surface as possible. 


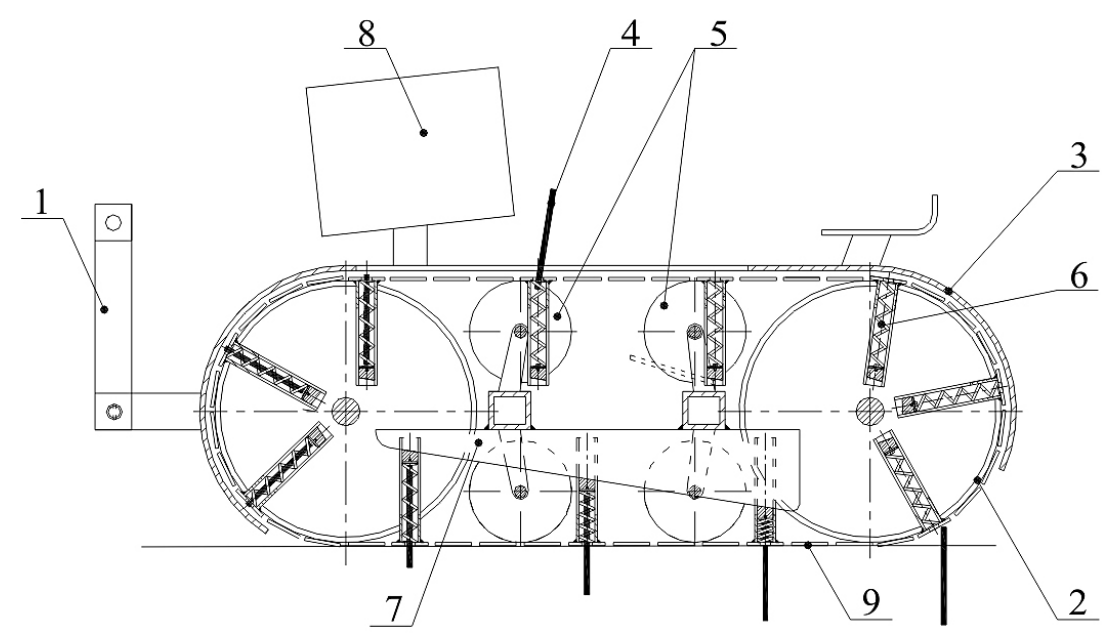

Fig. 6. The planter for cuttings of ligneous plants: 1 - three-point suspension system, 2 -wheel, 3 - housing, 4 - cutting, 5 - rollers, 6 - spring, 7 - wedge, 8 - reservoir for cuttings, 9 - track

The structure of a developed and patented mower for cutting down woody plants (Fig. 7) is composed of the frame (1), the three-point linkage (2) for attaching to the agricultural tractor and a working arm (3) coupled to the frame using an articulated joint (4). At the end of the working arm (3) a circular saw (6) is mounted. In order to provide the required power and efficiency, the saw is PTO driven.

The drive of the circular saw is transmitted from PTO by using a shaft (7), intersecting the axis gear (8) and the belt transmission (9). All movable elements of the machine are protected by safety guards. The prototype of the tractor-mounted mower for woody plants is presented in Fig. 8.

Table 1 presents the details of selected machines and devices used in the technology of establishing and cultivating herbal plants and species, especially willow.

\section{CONCLUSIONS}

Poland is a country with large production and processing capacities of herbs and spices. Among the plants cultivated in the country, about 170 species are used in the herbal industry. Cultivation of herbal plants and spices is not widespread, although it remains an alternative to the classical corn growing and allows for diversification of agricultural income sources, especially in small and medium-sized farms and ecological agricultural farms. The decreasing number of the small farms focused on animal production creates opportunities for increasing the share of herb and spices production in the crop share. A significant increase in the social awareness related to the ecological and health policy of European Union countries is also a factor determining the production of healthy food, herbs and spices. The grow-

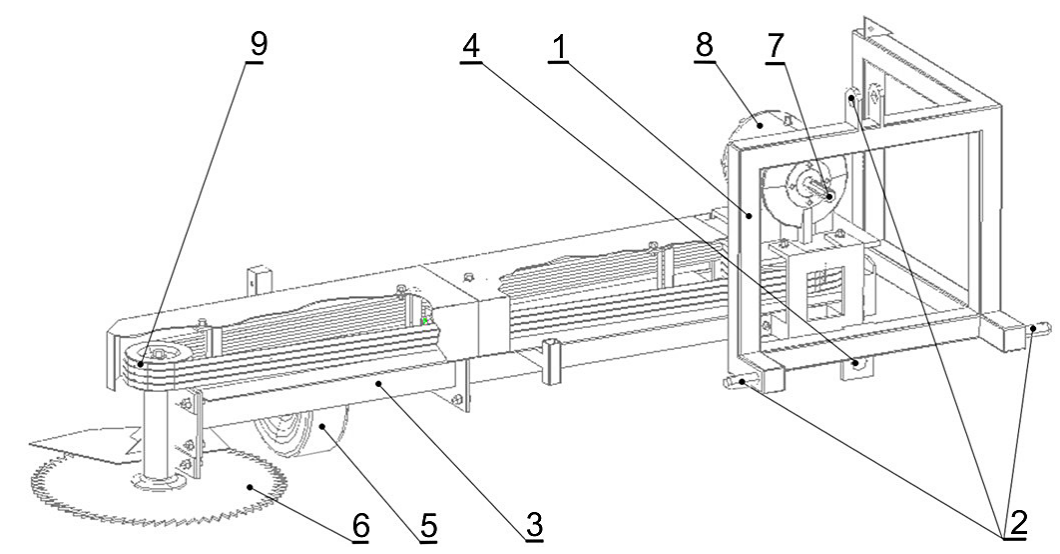

Fig. 7. Model of a tractor mower for woody plants: 1 - frame, 2 - three-point suspension system, 3 - working arm, 4 - articulated joint, 5 - supporting wheel, 6 - circular saw, 7 - shaft, 8 - intersecting axis gear, 9 - belt transmission 


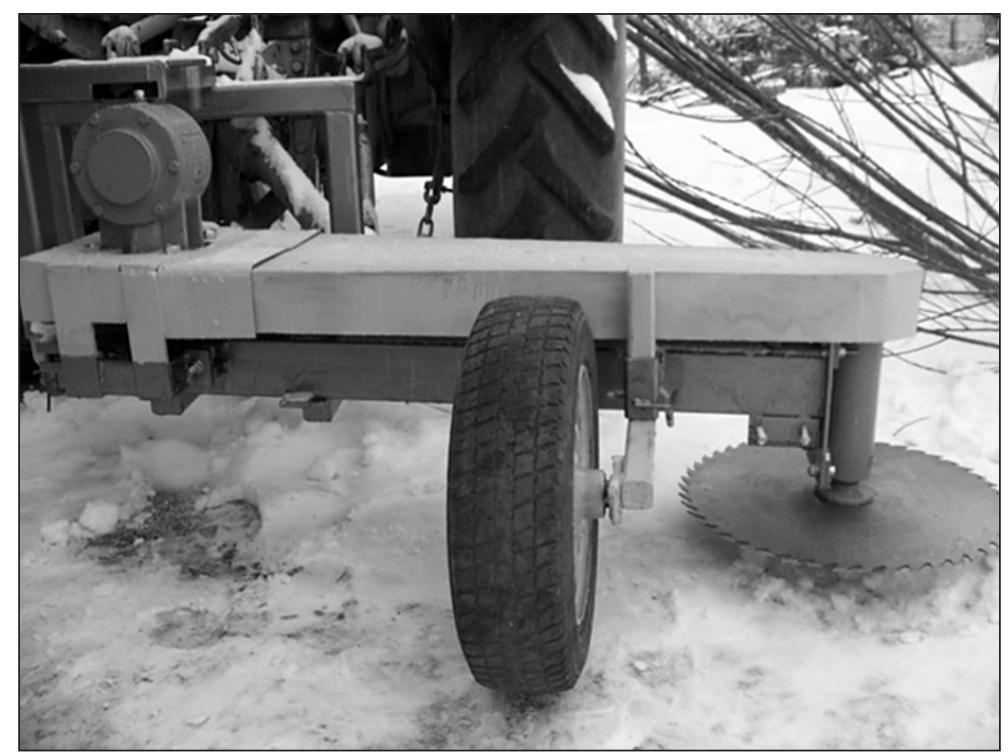

Fig. 8. Prototype of the mower for woody plants

Table 1. Machines and horticultural implements in the technology of herbal plants cultivation

\begin{tabular}{|l|l|c|c|}
\hline \multicolumn{1}{|c|}{ Authors } & \multicolumn{1}{|c|}{ Machine/device } & \multicolumn{1}{c|}{$\begin{array}{c}\text { Patent (P)/Utility } \\
\text { model (W) no. }\end{array}$} & Year \\
\hline Niemiec W., Puchała J. & Device for liquid dosage into soil & W-39050 & 1983 \\
\hline Niemiec W., Grygiel A., Kaszubski M. & $\begin{array}{l}\text { Device for fertilization of solid and liquid } \\
\text { fertilizers }\end{array}$ & P-176563 & 1995 \\
\hline Niemiec W. & $\begin{array}{l}\text { Device for collecting and measurement of } \\
\text { infiltrationed water in field research }\end{array}$ & W-64580 & 2007 \\
\hline Niemiec W., Skiba S., Ślenzak W. & Mower for tree-like plants & P-213402 & 2008 \\
\hline Niemiec W., Stachowicz F., Trzepieciński T. & Device for planting ligneous plants & W-66636 & 2011 \\
\hline Trzepieciński T. & Device for planting ligneous plants & P-400110 & 2015 \\
\hline
\end{tabular}

ing number of the energy willow plantations may contribute to a greater interest in the use of the willow bark for the medical purposes.

\section{REFERENCES}

1. Bergante S., Manzione M, Facciotto G. 2016. Alternative planting method for short rotation coppice with poplar and willow. Biomass Bioenergy, $87,39-45$.

2. Carmonia F., Pereira A.M.S. 2013. Herbal medicines: old and new concepts, truths and misunderstandings. Revista Brasileira de Farmacognosia, 23(2), 379-385.

3. Dimitriou I., Mola-Yudego B. 2017. Nitrogen fertilization of poplar plantations on agricultural land: effects on diameter increments and leaching. Scandinavian Journal of Forest Research, 32(8), 700-707.

4. Forster N., Ulrichs C., Zander M., Katzel R., Mewis I. 2008. Influence of the season on the salicylate and phenolic glycoside contents in the bark of
Salix daphnoides, Salix pentandra, and Salix purpurea. Journal of Applied Botany and Food Quality, 82(1), 99-102.

5. Habel A., Jucherski A., Niemiec W., Frankowski A., Kozakiewicz Z., Kaszubski M. 1990. Mechanical loader of manure. Utility Model No. W-52082.

6. Leonti M., Verpoorte R. 2017. Traditional Mediterranean and European herbal medicines. Journal of Ethnopharmacology, 199, 161-167.

7. Lubbe A., Verpoorte R. 2011. Cultivation of medicinal and aromatic plants for specialty industrial materials. Industrial Crops and Products, 34(1), 785-801.

8. Mahdi J.G. 2014. Medicinal potential of willow: A chemical perspective of aspirin discovery. Journal of Saudi Chemical Society, 14(3), 317-322.

9. Mahdi J.G., Mahdi A.J., Mahdi A.J., Bowen I.D. 2006. The historical analysis of aspirin discovery, its relation to the willow tree and anticancer potential. Cell Proliferation, 39(2), 147-155.

10. Mizak L., Gryko R., Kwiatek M., Parasion S. 2012. Probiotics in animal nutrition. Życie weterynaryjne, 89(9), 736-742 (in Polish). 
11. Newerli-Guz J. 2016. The cultivation of herbal plants in Poland. Roczniki Naukowe 18(3): 268- 274 (in Polish).

12. Niemiec W., Wójcik M. 2015. The possibilities of utilization of municipal sewage sludge in selected sewage-treatment plants. Zeszyty Naukowe Politechniki Rzeszowskiej - Mechanika, 87(4), 339-347 (in Polish).

13. Olewnicki D., Jabłońska L., Orliński P., Gontar Ł. 2015. Changes in Polish domestic production of herbal plants and in selected types of enterprises that process herbal plants in the context of the global increase in demand for these products. Zeszyty Naukowe SGGW, 15(1), 68-76 (in Polish).

14. Santangelo E., Scarfone A. Del Giudice A., Acampora A., Alfano V., Suardi A., Pari L. 2015. Harvesting systems for poplar short rotation coppice. Industrial Crops and Products, 75, 85-92.

15. Schmid B., Kötter I., Heide L. 2001. Pharmacokinetics of salicin after oral administration of standard willow bark extract. European Journal of Clinical Pharmacology, 57(5), 387-391.
16. Spinelli R., Schweier J., De Francesco F. 2012. Harvesting techniques for non-industrial biomass plantations. Biosystems Engineering, 113(4), 319-332.

17. Szczukowski S., Tworkowski J., Sulima P. 2002. Willow bark with a source of salicylic glycosides. Wiadomości Zielarskie, 44(1), 6-7 (in Polish).

18. Tripathy V., Basak B.B., Varghese T.S., Saha A. 2015. Residues and contaminants in medicinal herbs - A review. Phytochemistry Letters, 14, 67-78.

19. Trzepieciński T., Niemiec W., Stachowicz F. 2013. Selected design problems of mowers for felling woody plants and protection of green areas. Technika Rolnicza Ogrodnicza Leśna, 1, 13-15.

20. Vanbeveren, S.P.P., Schweier, J., Berhongaray, G., Ceulemans, R. 2015. Operational short rotation woody crop plantations: manual or mechanised harvesting. Biomass and Bioenergy, 72, 8-18.

21. Waliszewska B., Dukiewicz H. 2014. The use of willows in pharmacy. Zeszyty Naukowe Wydziału Nauk Ekonomicznych Politechniki Koszalińskiej, 18, 57-66 (in Polish). 